\title{
Effect of Storage Time on Cauda Epididymal Sperm Parameters of Nigerian Local Dogs
}

\author{
Uchenna Macnissi Chima', Adakole Hyacinth Abu', Philip Makama Dawuda ${ }^{2}$, \\ Aboh Iku Kisani'2, Terzungwe Ahemen ${ }^{3}$ \\ ${ }^{1}$ Department of Veterinary Physiology, Pharmacology and Biochemistry, College of Veterinary Medicine, \\ Federal University of Agriculture, Makurdi, Nigeria \\ ${ }^{2}$ Department of Veterinary Surgery and Theriogenology, College of Veterinary Medicine, Federal \\ University of Agriculture, Makurdi, Nigeria \\ ${ }^{3}$ Department of Animal Breeding and Physiology, College of Animal Science, Federal University of Agriculture, \\ Makurdi, Nigeria \\ Email: adakoleabu1@gmail.com
}

How to cite this paper: Chima, U.M., Abu, A.H., Dawuda, P.M., Kisani, A.I. and Ahemen, T. (2017) Effect of Storage Time on Cauda Epididymal Sperm Parameters of Nigerian Local Dogs. Open Journal of Veterinary Medicine, 7, 151-161.

https://doi.org/10.4236/ojvm.2017.711016

Received: September 30, 2017

Accepted: November 21, 2017

Published: November 24, 2017

Copyright (c) 2017 by authors and Scientific Research Publishing Inc. This work is licensed under the Creative Commons Attribution International License (CC BY 4.0).

http://creativecommons.org/licenses/by/4.0/

\section{Open Access}

\begin{abstract}
Aim: Storage of testes-epididymides at refrigeration temperature is a promising method of short-term sperm preservation for use in reproductive biotechnology in dogs. This study aimed to determine the effect of storage time at $4^{\circ} \mathrm{C}$ on the quality of Nigerian local dogs' cauda epididymal spermatozoa recovered post-castration. Materials and Methods: Testes along with their epididymides collected immediately after castration of local dogs were either processed immediately ( 0 th hour) or stored at $4^{\circ} \mathrm{C}$ in the refrigerator for 12 th, 24 th or 48th hours and then processed. Each storage group comprised 5 pairs of testes-epididymides. Sperm motility, concentration, livability, acrosome integrity and morphology from the various storage groups were evaluated and means with standard error of the mean $( \pm$ SEM) were recorded. Results: Mean percent sperm motility at 0th hour $(77.0 \pm 2.6)$ decreased significantly $(\mathrm{p}<$ $0.05)$ after 12 hours $(68.0 \pm 1.2), 24$ hours $(66.0 \pm 2.4)$ and 48 hours $(60.0 \pm$ $1.6)$ of storage at $4^{\circ} \mathrm{C}$. No significant difference $(\mathrm{p}>0.05)$ was found when the mean sperm concentrations $\left(\times 10^{7} / \mathrm{ml}\right)$ of the storage groups $(5.86 \pm 47,5.24 \pm$ 26 and $5.38 \pm 31)$ were compared with the control $(6.48 \pm 0.75)$. Mean percent sperm livability did not differ significantly $(\mathrm{p}>0.05)$ between the 0 th, 12th, 24 th and 48th hour groups $(86.4 \pm 1.5,78.0 \pm 3.1$ and $75.0 \pm 1.8$ respectively). However, there was a significant decrease $(\mathrm{p}<0.05)$ in mean percent sperm livability after 48 hours of storage $(69.8 \pm 4.2)$ as compared with the 0th hour group. No significant difference $(p>0.05)$ was detected in the mean percent acrosome integrity between the 0 th, 12 th, 24th and 48th hour groups $(90.0 \pm$ $1.5,83.0 \pm 3.5,84.6 \pm 4.6$ and $82.2 \pm 3.9$ respectively). A significant increase (p
\end{abstract}


$<0.05)$ in percent sperm morphological defect was detected after 48 hours of storage $(37.6 \pm 2.7)$ as compared to the 0th hour group $(27.4 \pm 2.0)$. Conclusion: The current study has shown that viable spermatozoa can be recovered after 48 hours of storage at $4^{\circ} \mathrm{C}$ of the cauda epididymides of Nigerian local dogs.

\section{Keywords}

Castration, Testes, Epididymides, Nigerian Local Dogs, Spermatozoa

\section{Introduction}

Reproduction in dogs can be achieved naturally through mating or artificially through assisted reproductive technologies such as artificial insemination (AI), in vitro fertilization (IVF), and intracytoplasmic sperm injection (ICSI). Effective preservation of semen is essential to the success of these reproductive technologies [1]. Chilling and freezing of semen are two ways by which semen could be preserved for use in assisted reproductive technologies. Interest in the use of cauda epididymal spermatozoa for assisted reproductive technologies has grown recently [2] [3] [4]. Cauda epididymal spermatozoa can be recovered either during castration or post mortem. Pregnancies and live births have been reported in horse [3], sheep [5], rat [6] [7], cow [8] [9], goat [10], human [11] [12] [13] and also in dogs [4] [14] when epididymal spermatozoa were used. Recovery of the epididymal spermatozoa helps to ensure that the genetic materials of a highly priced or valuable animal are not lost.

Retrieval and short term storage of the epididymal sperm under refrigeration temperature for transport to sperm banks for long term cryopreservation or to areas where they could be used immediately for artificial insemination provides an avenue to preserve the genetic materials of such an animal. The conditions (temperature, time, and environment) under which the epididymides are transported to the laboratory or sperm bank could affect the quality of the spermatozoa. To the best of our knowledge, little work has been done on the effects of cold storage on the quality of cauda epididymal spermatozoa of Nigerian local dogs.

\section{Materials and Methods}

Ethical approval: This study was conducted in conformity with the ethics guidelines of the College of Veterinary Medicine, Federal University of Agriculture, Makurdi, Nigeria.

\subsection{Study Location}

The research was carried out at the Theriogenology laboratory of the Veterinary Teaching Hospital Annex, Federal University of Agriculture, Makurdi. Makurdi is located in the southern guinea savannah, and at Latitude $7^{\circ} 14^{\prime}$ North and Lon- 
gitude $8^{\circ} 21^{\prime}$ East. The area has a warm temperature range of $24^{\circ} \mathrm{C}$ to $36^{\circ} \mathrm{C}$. High temperatures are experienced between late February and April in this area. The level of rainfall is between 508 and $1016 \mathrm{~mm}$. Two weather seasons are experienced: the rainy season (May-October) and dry season (November-April) [15].

\subsection{Sample Collection and Experimental Design}

The animals used in this study were 20 apparently healthy mature male dogs aged 2 - 5 years with body weights ranging from 9.8 to $18 \mathrm{~kg}$ (mean: $13 \pm 1.55$ ). The dogs were housed in the dog kennels $(1.5 \times 1.43 \times 2.2 \mathrm{~m})$ at the Veterinary Teaching Hospital Annex of the Federal University of Agriculture Makurdi. They were fed once daily with homemade food and drinking water was provided ad libitum.

Testes along with their epididymides were surgically removed under general anaesthesia. The inguinal region of each dog was shaved and aseptically prepared for surgery. The dogs were premedicated with atropine sulphate (Pauco Pharmaceuticals, Nigeria) $(0.04 \mathrm{mg} / \mathrm{kg})$ and xylazine (Wuhan Wang Lianshang Biotechnology, China) $(2 \mathrm{mg} / \mathrm{kg})$ intramuscularly. The animals were placed indorsal recumbence with the hind legs extended. They were then draped and general anaesthesia was induced using thiopental sodium (Pan Pharma, S.A. France) at $10 \mathrm{mg} / \mathrm{kg}$ intravenously. Each testis was advanced to the prescrotalposition and a midline incision about $3-4 \mathrm{~cm}$ in length was made on the skin anterior to the scrotum or posterior to the bulbourethral gland of the penis. The left and the right testicles were exteriorized through the incision by pressure over the scrotum. The tunica vaginalis covering the testis was incised. The spermatic cord was clamped with two artery forceps, and two ligatures using chromic catgut size 0 (Agary, Nigeria) was applied above the upper forceps and the second ligature below the lower forceps. The cord was then severed between the two forceps and the lower forceps was then slowly released. Following complete arrest of haemorrhage, deep and superficial subcutaneous layers and sub-dermal skin were closed with size 0 chromic catgut in a simple interrupted fashion. The skin was then sutured with interrupted suture pattern using size 3 nylon suture material (Agary, Nigeria).

A combination of procaine penicillin $\mathrm{G}$ (Zhongnuo pharmaceuticals, China) $(200,000 \mathrm{IU} / \mathrm{kg}$ ) and streptomycin (Shanxi pharmaceuticals, China) (20 $\mathrm{mg} / \mathrm{kg}$ ) was administered for 5 days post-castration and pentazocine (Emzor pharmaceuticals, Nigeria), was administered at $3 \mathrm{mg} / \mathrm{kg}$ for post-operative analgesia.

Group I comprised 5 pairs of testicles with their epididymides that were processed at room temperature immediately after excision (0th hour). Each of groups II, III and IV comprised 5 pairs of testicles with their epididymides that were processed after storage in the refrigerator at $4^{\circ} \mathrm{C}$ for 12th, 24th and 48th hours respectively. 


\subsection{Testicle Storage Procedure}

The tunica vaginalis and blood vessel leading to the testes and vas deferens were carefully trimmed off using scissors. The excised testes were covered with two layers of sterile gauze and placed in a rectangular stainless steel surgical pan withan airtight stainless steel lid and lined with two layers of sterile gauze. Sterile physiological saline (Juhel pharmaceuticals, Nigeria) was added to the gauze until they were completely wet to prevent the samples from drying out. The pan was then placed in a standard refrigerator at $4^{\circ} \mathrm{C}$.

\subsection{Experimental Procedure}

The stored testes and epididymides were warmed to room temperature for 15 minutes. The testes and epididymides were then immersed in a water bath at $37^{\circ} \mathrm{C}$ for 5 minutes until their outer surfaces were softened. The excised testes and epididymides were separated using a scalpel blade (size 23, Life care medical, Nigeria). Sperm cells were recovered from the cauda epididymis at room temperature $\left(22^{\circ} \mathrm{C}\right.$ to $\left.28^{\circ} \mathrm{C}\right)$ by the incision method. Several incisions were made on the lower end of the epididymis to enable sperm cells swim out into prewarmed $\left(38^{\circ} \mathrm{C}\right)$ three milliliters of $2.9 \%$ sodium citrate buffer in a Petri dish (95 $\mathrm{mm})$. The cauda epididymis was then severed into the Petri dish containing $2.9 \%$ sodium citrate buffer solution and placed in a water bath at $37^{\circ} \mathrm{C}$ for 30 minutes.

\subsubsection{Determination of Spermatozoan Progressive Motility} Spermatozoan progressive motility of different storage groups including control (0th-hour group) were evaluated by placing a drop $(10 \mu \mathrm{L})$ of sperm sample on a grease-free slide. A cover slip was put over the drop and examined under the

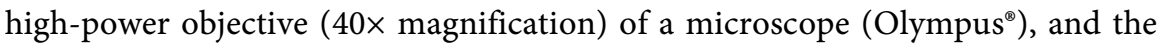
percentage of progressive motility was determined [16].

\subsubsection{Determination of Sperm Concentration}

Epididymal sperm concentration of each sample was determined using the improved Neubauer haemocytometer after appropriate dilution in $0.05 \%$ formol-saline [15].

\subsubsection{Determination of Spermatozoan Livability}

Livability of sperm cells was determined by placing a drop $(10 \mu \mathrm{L})$ of sperm sample on a clean, grease-free slide and mixed with a single drop of eosin-nigrosin stain. The spermatozoa were allowed to interact with the stain for at least $2 \mathrm{~min}$ and then a smear was prepared. The prepared smear was air-dried and examined under oil immersion objective (100× magnification). Spermatozoa that stained either partially or completely were considered as dead, and spermatozoa that appeared colourless were considered as alive. Two hundred spermatozoa were randomly examined across different fields and the percentage of live sperm cells was determined. The mean results were expressed as percent [17]. 


\subsubsection{Determination of Acrosome Integrity}

Acrosome status was determined by briefly adding a small $(10 \mu \mathrm{L})$ drop of the sample on a clean slide and making a smear. The smear was air-dried and kept in Hancock's fixative for $15-20$ min in a coupling jar. After the prescribed time interval, the slides were washed under slow running tap water for another 15 20 minutes and finally rinsed with distilled water. The slides were kept in a coupling jar containing Giemsa working solution overnight. The next day, the stained slides were rinsed with slow running tap water, air-dried, and observed under oil immersion objective (100× magnification). Two hundred spermatozoa were randomly examined across different fields and the percentage of spermatozoa with intact acrosomes was determined. The mean results were expressed as percent intact acrosomes [18].

\subsubsection{Determination of Sperm Morphological Abnormality}

Sperm morphological abnormality was determined by viewing the Giemsa stained slides. Two hundred spermatozoa were examined across different fields and the percentage of spermatozoa with morphological abnormalities was determined. The mean results were expressed as percent morphological abnormality.

\subsection{Statistical Analysis}

Data collated were analyzed by One-way analysis of variance (ANOVA) and expressed as mean \pm standard error of the mean using GraphPad Prism version 7.0 for windows. The differences between means were analyzed by Tukey's multiple comparisons test. The level of significance was set at $5 \%$.

\section{Results}

Mean percent sperm motility of each storage time group is presented in Table 1 . Sperm motility decreased significantly $(\mathrm{p}<0.05)$ after 12th, 24th and 48th hours compared to the 0th hour group. There was no significant difference $(p>0.05)$ between sperm motility of the 12th hour group and 24th hour group. However, there was a significant difference $(\mathrm{p}<0.05)$ between the 12th hour group and the 48th hour group. Furthermore, no significant difference $(p>0.05)$ was found between the 24th hour group and 48th hour group. No significant difference $(p>0.05)$ was detected in the mean sperm concentration between the 0th, 12th, 24th and 48th hour groups.

No significant difference was detected in the mean percent sperm livability between the 0th, 12th, and 24th hour groups ( $p>0.05)$. However, the sperm livability of the 48th hour group was significantly lower $(\mathrm{p}<0.05)$ than that of the 0 th hour group. Furthermore, no significant difference $(p>0.05)$ was detected between the sperm livability of the 12th, 24th and 48th hour groups. No significant difference $(p>0.05)$ was detected in the mean percent acrosome integrity between 0th, 12th, 24th and 48th hour groups (Table 1).

There was an increase in sperm abnormality relative to storage time (Table 1). The mean percent sperm abnormality in the 48th hour storage group was 
Table 1. Mean ( \pm SEM) Cauda epididymal sperm parameters of Nigerian local dogs recovered post-castration, processed immediately after recovery without storage (0th hour) and after storage at $4^{\circ} \mathrm{C}$ for 12,24 and 48 hours.

\begin{tabular}{ccccc}
\hline Parameter & 0th hour & 12th hour & 24th hour & 48th hour \\
\hline $\begin{array}{c}\text { Sperm } \\
\text { motility (\%) }\end{array}$ & $77.00 \pm 2.55$ & $68.00 \pm 1.23^{\mathrm{b}}$ & $66.00 \pm 2.45^{\mathrm{bc}}$ & $60.00 \pm 1.58^{\mathrm{c}}$ \\
$\begin{array}{c}\text { Sperm concentration } \\
\left(\times 10^{7} / \mathrm{ml}\right)\end{array}$ & $6.48 \pm 0.75$ & $5.86 \pm 47$ & $5.24 \pm 26$ & $5.38 \pm 31$ \\
$\begin{array}{c}\text { Sperm } \\
\text { livability (\%) }\end{array}$ & $86.40 \pm 1.50^{\mathrm{a}}$ & $78.00 \pm 3.11^{\mathrm{ab}}$ & $75.00 \pm 1.82^{\mathrm{ab}}$ & $69.80 \pm 4.21^{\mathrm{b}}$ \\
$\begin{array}{c}\text { Acrosome integrity (\%) } \\
\begin{array}{c}\text { Morphologically } \\
\text { abnormal sperm (\%) }\end{array}\end{array}$ & $90.00 \pm 1.52$ & $83.00 \pm 3.52$ & $84.60 \pm 4.63$ & $82.20 \pm 3.85$ \\
\hline
\end{tabular}

Means with different alphabet superscripts in the same row are significantly different $(\mathrm{P}<0.05)$. SEM $=$ Standard Error of the Mean.

significantly higher $(\mathrm{p}<0.05)$ than the mean percent sperm abnormality in the 0 th hour group. No significant difference $(\mathrm{p}>0.05)$ was detected when mean percent sperm abnormality in the 0th, 12th and 24th hour storage groups were compared.

\section{Discussion}

The method of recovery and cold storage of cauda epididymal spermatozoa at $4^{\circ} \mathrm{C}$ has been reported to be an effective way to preserve spermatozoa for use in the short term in Red Sokoto bucks [15], ram [19], red deer [20] and Beagle dogs [4]. Refrigeration slows down metabolic functions, hence allowing the spermatozoa to survive for longer periods than at room temperature [21]. However, long term cold storage of spermatozoa may lead to a reduction in their motility and damage to the integrity of their membranes and morphology [22]. Some researchers suggested that these changes might be attributed to the accumulation of toxic products of metabolism, especially reactive oxygen species (ROS) [23]. Oxidative stress originating from the generation of reactive oxygen species (ROS) causes structural damages to cellular components. Epididymal spermatozoa may be more susceptible to oxidative stress than ejaculated spermatozoa since they are not exposed to seminal plasma which contains the complex secretions of the accessory sex glands which are regarded as the major source of antioxidant protection for spermatozoa [24].

Another possible cause of the decrease in epididymal sperm quality after 48 hours of storage at $4^{\circ} \mathrm{C}$ is change in osmotic pressure of the epididymal fluid. The osmotic pressure of epididymal fluid has been reported to be higher than that of seminal plasma and fluid in the reproductive tract of females [25]. When spermatozoa are exposed to the lower osmotic pressure of seminal plasma during ejaculation, they can reverse the low osmotic-pressure induced changes in volume and adapt to the pressure [4]. It is conceivable that changes in osmotic 
pressure of the epididymal fluid due to storage of the epididymides at $4^{\circ} \mathrm{C}$ might have contributed to the decrease in sperm quality and increased incidence of abnormal sperm after 48 hours of storage. Variations in the quality of epididymal sperm cells that have been stored at $4^{\circ} \mathrm{C}$ can be attributed to handling conditions or species differences [15] [26].

It was found that epididymal sperm ofthe local dogs were still motile after 48 hours of storage at $4^{\circ} \mathrm{C}$, although, motility decreased significantly $(\mathrm{p}<0.05)$ compared to the 0th hour storage group. Some researchers recorded motility of $61 \%$ after 48 hours of storage at $4^{\circ} \mathrm{C}$ of epididymal spermatozoa of beagle dogs [4]. This was cryopreserved and afterwards used for intrauterine inseminations which resulted in a conception rate of $80 \%$ ( 4 out of 5 bitches). It was observed that the motility of fresh semen decreased from $84 \%$ to $76 \%$ after 24 hours and to $63 \%$ after 48 hours [27]. However, these researchers reported that pregnancy rates obtained following artificial insemination with fresh dog semen was $94 \%$ (17/18) while for dog semen that had been extended and chilled for 24 hours and 48 hours were $90 \%(9 / 10)$ and $100 \%(10 / 10)$ respectively. Although these results were obtained with ejaculated semen rather than epididymal sperm, it offers some hope that dog epididymal sperm that has been stored at $4^{\circ} \mathrm{C}$ for 48 hours, with a motility of over $60 \%$ could be fertile enough to be used in assisted reproductive technologies. There are reports on other species of animals in which epididymal sperm motility has been observed after some days of storage at $4^{\circ} \mathrm{C}$ $5^{\circ} \mathrm{C}$. Some scientists reported an epididymal sperm motility of $50.60 \% \pm 0.48 \%$ after 48 hours of storage of epididymides of Red Sokoto bucks at $4^{\circ} \mathrm{C}$ [15]. However, 57\% motility was obtained for cat epididymal sperm after overnight cold storage at $5^{\circ} \mathrm{C}$ [28]. Similarly, other investigators were able to obtain $5.5 \%$ epididymal spermatozoa motility even after 20 days of storage of mouse cadavers at $4^{\circ} \mathrm{C}$ [29]. A study has shown that $44.17 \pm 1.53 \%$ of spermatozoa were motile after 48 hours of storage of ram epididymal spermatozoa at $4^{\circ} \mathrm{C}$ [19]. After 108 hours of storage at $4^{\circ} \mathrm{C}$ of African buffalo epididymal sperm, a motility of approximately $10 \%$ was observed [30]. A study on epididymal sperm motility showed $42.8 \%$ for bulls aged between 37 - 51 weeks and 55.9\% for bulls aged between 52 - 115 weeks old after 48 hours of storage of their epididymides at $5^{\circ} \mathrm{C}$ [31]. Camel epididymal sperm diluted with tris-fructose extender supplemented with antioxidants were still motile (64\%) after 48 hours of storage at $5^{\circ} \mathrm{C}$ [24].

There was no significant difference $(\mathrm{p}>0.05)$ in the mean epididymal sperm concentration of different storage groups. This is in agreement with the findings of [32] in Beagle dogs. Epididymal sperm concentration varied among the animals. The variations could be due to the use of dogs of different ages and sizes in each group. Mean epididymal sperm concentration obtained in this study was lower than the value reported by [32] in Beagle dogs $\left(61.5 \pm 10.0 \times 10^{7} / \mathrm{ml}\right)$. This difference could be due to breed variations.

There was a gradual decline in livability as storage time increased in this study. However, a mean epididymal sperm livability of $69.8 \%$ was obtained after 48 hours of storage at $4^{\circ} \mathrm{C}$. A researcher reported a similar trend in livability of 
epididymal spermatozoa in a variety of breeds of dogs whose epididymal sperm livability decreased significantly $(\mathrm{p}<0.05)$ from $90.3 \% \pm 1.2 \%$ at 0 th hour to $80.8 \% \pm 1.9 \%$ after 48 hours of storage at $4^{\circ} \mathrm{C}$ [1]. However, [4] and [33] did not detect any significant difference $(\mathrm{p}>0.05)$ in the livability of canine epididymal spermatozoa after 48 hours of storage at $4^{\circ} \mathrm{C}$. Furthermore, a study showed that though there was no significant difference $(\mathrm{p}>0.05)$ in sperm livability after 48 hours (day 2), the sperm livability decreased significantly after 96 hours of storage of cauda epididymal spermatozoa from a variety of pure and mixed breeds of dogs at $5^{\circ} \mathrm{C}$ [34]. Taken together, these researchers observed variations in the value of livability of canine epididymal spermatozoa after 48 hours of refrigeration.

It is conceivable that even after 48 hours of storage of canine epididymal spermatozoa at $4^{\circ} \mathrm{C}$, the spermatozoa could still be viable enough to be cryopreserved or used in assisted reproductive technologies. The findings in this study were in accordance with the report of [15] on Red Sokoto bucks, whose epididymal sperm livability declined in a storage-time dependent manner. The success of assisted reproductive techniques such as artificial insemination (AI) and in vitro fertilization (IVF) depends on the use of a sufficient number of motile acrosome intact sperm that has the potential of fertilizing the oocyte [35]. An intact acrosome prevents the loss of acrosomal enzymes such as hyaluronidase until they are released during acrosome reaction in the female reproductive tract prior to fertilization [36]. In this study, it was observed that after 48 hours of storage of the epididymides at $4^{\circ} \mathrm{C}$, there was no significant difference $(\mathrm{p}>0.05)$ in the mean percent acrosome integrity of the cauda epididymal spermatozoa between different storage groups. This was in agreement with the findings of [4] in beagle dogs and [34] in a mixture of pure and mixed breeds of dogs. Similar findings were obtained in Red Sokoto goats after storage of their epididymides at $4^{\circ} \mathrm{C}$ for 48 hours [15] and also in ram [19].

The percentage of sperm morphological abnormality increased with storage time in our study. This was in agreement with the findings of [4] in Beagle dogs and [37] in goats. This could be attributed to the effects of changes in osmotic pressure of the epididymal fluid due to storage at low temperature $\left(4^{\circ} \mathrm{C}\right)$.

Accidents involving dogs getting hit by cars are quite common in our environment. Results of our study suggest that viable spermatozoa can be recovered from cauda epididymides even if dogs are incapacitated. This study also suggests that cauda epididymal sperm cells could be useful in assisted reproductive technologies in dogs and other animal species.

\section{Conclusion}

The current study has shown that viable spermatozoa can be recovered from the epididymides of our local dogs after storage at $4^{\circ} \mathrm{C}$ for 48 hours. The findings of this study demonstrate a window of opportunity for recovery of spermatozoa of genetically valuable local dogs that are physically incapacitated. However, further 
studies are needed on the fertilizing capabilities of cold stored epididymal sperm of local dogs to enhance their usability.

\section{References}

[1] Stilley, K. (2001) Survival of Canine Epididymal Sperm under Cooled and Frozen-Thawed Conditions. M.Sc. Thesis, Department of Animal Sciences, Graduate Faculty of the Louisiana State University and Agricultural and Mechanical College, Baton Rouge, Louisiana, $145 \mathrm{p}$.

[2] Kim, M.J., Oh, H.J., Kim, G.A., Park. J.E., Jang, G., Kang, S.K., Ra, J.C. and Lee, B.C. (2012) Lessons Learned from Cloning Dogs. Reproduction in Domestic Animals, 47, 115-119. https://doi.org/10.1111/j.1439-0531.2012.02064.x

[3] Melo, C.M., Melo, F.O., Papa, E.G., Fioratti, A.I., Villaverde, S.B., Avanzi, B.R., Monteiro, G., DellAqua, J.A., Pasquini, D.F. and Alvarenga. M.A. (2008) Comparison of Three Different Extenders for Freezing Epididymal Stallion Sperm. Animal Reproduction Science, 107, 331 (Abstract). https://doi.org/10.1016/j.anireprosci.2008.05.108

[4] Hori, T., Hagiuda, K., Endo, S., Hayama, A., Kawakami, E. and Tsuitsui, T. (2005) Unilateral İntrauterine İnsemination with Cryopreserved Caudal Epididymal Sperm Recovered from Refrigerated Canine Epididymides. Journal of Veterinary Medical Science, 67, 1141-1147. https://doi.org/10.1292/jvms.67.1141

[5] Ehling, C., Rath, D., Struckmann, C., Frenzel, A. and Schindler, L. (2006) Utilization of Frozen-Thawed Epididymal Ram Semen to Preserve Genetic Diversity in Scrapie Susceptible Sheep Breeds. Theriogenology, 66, 2160-2164. https://doi.org/10.1016/j.theriogenology.2006.07.003

[6] Nakatsukasa, E., Inomata, T., Ikeda, T., Shino, M. and Kashiwazaki, N. (2001) Generation of Live Rat Offspring by Intrauterine Insemination with Epididymal Spermatozoa Cryopreserved at $-196^{\circ}$ C. Reproduction, 122, 463-467.

https://doi.org/10.1530/rep.0.1220463

[7] Kim, S. and Agca, Y. (2013) Effects of Iodixanol during Rat Epididymal Sperm Cryopreservation. Cryobiology, 67, 432. https://doi.org/10.1016/j.cryobiol.2013.09.127

[8] Graff, K.J., Chandler, J.E., Reggio, B.C., Lim, J.M., Canal, A., Carter, J.A., Meintjes M. and Godke, R.A. (1996) Pregnancies Obtained from IVF with Noncapacitated Epididymal Bovine Spermatozoa. Proceedings of the 3rd International Meeting on Biotechnology and Animal Reproduction, Cairo, 2-6 November 1996, 19-21.

[9] Guerrero, C.A., Gentry, G.T. and Saenz, J. (2009) Birth of Calves after Artificial Insemination with Cryopreserved Bovine Epididymal Spermatozoa Harvested from Post-Mortem Bulls. Reproduction, Fertility and Development, 21, 105.

[10] Blash, S., Melican, D. and Gavin, W. (2000) Cryopreservation of Epididymal Sperm Obtained at Necropsy From Goats. Theriogenology, 54, 899-905.

https://doi.org/10.1016/S0093-691X(00)00400-3

[11] Temple-Smith, P.D., Southwick, G.J., Yates, C.A., Trounson, A.O. and De Kretser, D.M. (1985) Human Pregnancy by In Vitro Fertilization (IVF) Using Sperm Aspirated from the Epididymis. Journal of In Vitro Fertilization and Embryo Transfer, 2, 119-222. https://doi.org/10.1007/BF01131497

[12] Bonduelle, M., Liebaers, I., Deketelaere, V., Derde, M.P., Camus, M., Devroey, P. and Van Steirteghem, A. (2002) Neonatal Data on a Cohort of 2,889 İnfants Born after ICSI (1991-1999) and of 2,995 İnfants Born after IVF (1983-1999). Human 
Reproduction, 17, 671-694. https://doi.org/10.1093/humrep/17.3.671

[13] Glina, S., Fragoso, J.B., Martins, F.G., Soares, J.B., Gallupo, A.G. and Wonchockier, R. (2003) Percutaneous Epididymal Sperm Aspiration (PESA) in Men with Obstructive Azoospermia. International Brazilian Journal of Urology, 29, 141-146.

[14] Marks, S.L., Dupuis, J., Mickelsen, W.D., Memon, M.A. and Platz, C.C. (1994) Conception by Use of Post-Mortem Epididymal Semen Extraction in a Dog. Journal of the American Veterinary Medical Association, 204, 1639-1640.

[15] Zemjanis, R. (1970) Collection and Evaluation of Semen. In: Diagnostics and Therapeutic Techniques in Animal Reproduction, 2nd Edition, Williams and Wilson Co., Baltimore, MD, 139-156.

[16] Abu, A.H., Kisani, A.I. and Ahemen, T. (2016) Evaluation of Sperm Recovered from Cauda Epididymides of Red Sokoto Bucks. Veterinary World, 9, 1440-1444. https://doi.org/10.14202/vetworld.2016.1440-1444

[17] Blom, E. (1977) Sperm Morphology with Reference to Bull Infertility. In: Some Papers Contributed to the 1 st All India Symposiums on Animal Reproduction, Punjab Agricultural University, Ludhiana, India, 66-81.

[18] Watson, P.F. (1975) Use of a Giemsa Stain to Detect Changes in Acrosomes of Frozen Ram Spermatozoa. Veterinary Records, 97, 12-15. https://doi.org/10.1136/vr.97.1.12

[19] Mir, S.S., Lone, F.M., Khan, M.Z., Malik, A.A., Islam, R. and Sofik, A. (2012) Effect of Cold Storage Period on the Quality of Ram Cauda Epididymal Spermatozoa Recovered Post-Mortem. Turkish Journal of Veterinary and Animal Sciences, 36, 683-687.

[20] Soler, A.J., Esteso, M.C., Fernandez-Santos, M.R. and Garde, J.J. (2005) Characteristics of Iberian red deer (Cervus elephushispanicus) Spermatozoa Cryopreserved after Storage at $5^{\circ} \mathrm{C}$ in the Epididymis for Several Days. Theriogenology, 64, 1503-1517. https://doi.org/10.1016/j.theriogenology.2005.03.013

[21] Hishinuma, M., Suzuki, K. and Sekine, J. (2003) Recovery and Cryopreservation of Sika Deer (Cervus nippon) Spermatozoa from Epididymides Stored at $4^{\circ} \mathrm{C}$. Theriogenology, 59, 813-820. https://doi.org/10.1016/S0093-691X(02)01154-8

[22] Jarosz, L.,Grądzki, Z., Kalinowski, M. and Laskowska, E. (2016) Quality of Fresh and Chilled-Stored Raccoon Dog Semen and İts İmpact on Artificial İnsemination Efficiency. BMC Veterinary Research, 12, 224.

https://doi.org/10.1186/s12917-016-0858-6

[23] Santos, N.A., Bezerra, C.S., Martins, N.M., Curti, C., Blanchi, M.L. and Santos, A.C. (2008) Hydroxyl Radical Scavenger Ameliorates Cisplatin-İnduced Nephrotoxicity by Preventing Oxidative Stress, Redox State Unbalance, İmpairment of Energic Metabolism and Apoptosis in Rat Kidney Mitochondria. Cancer Chemotherapy and Pharmacolology, 61, 145-155. https://doi.org/10.1007/s00280-007-0459-y

[24] El-Harairy, M.A., Abd El-Razek, I.M., Abdel-Khalek, E.A., Shamiah, S.M., Zaghloul, H.K. and Khalil, W.A. (2016) Effect of Antioxidants on the Stored Dromedary Camel Epididymal Sperm Characteristics. Asian Journal of Animal Sciences, 10, 147-153. https://doi.org/10.3923/ajas.2016.147.153

[25] Jones, R. (1978) Comparative Biochemistry of Mammalian Epididymal Plasma. Comparative Biochemistry and Physiology Part B: Comparative Biochemistry, 61, 365-370. https://doi.org/10.1016/0305-0491(78)90138-4

[26] Lubbe, K., Bartels, P., Kilian, I., Friedmann, Y. and Godke, R.A. (2000) Comparing Motility and Morphology of Horse, Zebra and Rhinoceros Epididymal Spermatozoa When Cryopreserved with Two Different Cryodiluents or Stored at $4^{\circ} \mathrm{C}$. Therioge- 
nology, 53, 338 .

[27] Pinto, C.R.F., Paccamonti, D.L. and Eilts, B.E. (1999) Fertility in Bitches Artificially Inseminated with Extended, Chilled Semen. Theriogenology, 52, 609-616. https://doi.org/10.1016/S0093-691X(99)00156-9

[28] Goodrowe, K.L. and Hay, M. (1993) Characteristics and Zona Binding Ability of Fresh and Cooled Domestic Cat Spermatozoa. Theriogenology, 40, 967-975. https://doi.org/10.1016/0093-691X(93)90365-C

[29] Kishikawa, H., Tateno, H. and Yanagimachi, R. (1999) Fertility of Mouse Spermatozoa Retrieved from Cadavers and Maintained at $4{ }^{\circ} \mathrm{C}$. Journal of Reproduction and Fertility, 116, 217-222. https://doi.org/10.1530/jrf.0.1160217

[30] Kilian, I., Lubbe, K. Bartels, P., Friedmann, Y. and Denniston, R.S. (2000) Evaluating Epididymal Sperm of African Wild Ruminants: Longevity When Stored at $4^{\circ} \mathrm{C}$ and Viability Following Cryopreservation. Theriogenology, 53, 336.

[31] Strand, J., Ragborg, M.M., Pederson, H.S., Kristensen, T.N., Pertoldi, C. and Callesen, H. (2016) Effects of Post-Mortem Storage Conditions of Bovine Epididymides on Sperm Characteristics: Investigating a Tool for Preservation of Sperm from Endangered Species. Conservation Physiology, 4, cow069.

https://doi.org/10.1093/conphys/cow069

[32] Hori, T., Ichikawa, M., Kawakami, E. and Tsutsui, T. (2004) Artificial Insemination of Frozen Epididymal Sperm in Beagle Dogs. Journal of Veterinary Medical Science, 66, 37-41. https://doi.org/10.1292/jvms.66.37

[33] Yu, I. and Leibo, S.P. (2002) Recovery of Motile, Membrane İntact Spermatozoa from Canine Epididymis, Stored for 8 Days at $4^{\circ} \mathrm{C}$. Theriogenology, 57, 1179-1190. https://doi.org/10.1016/S0093-691X(01)00711-7

[34] Ponglowhapan, S., Chatdarong, K., Sirivaidyapong, S. and Lohachit, C. (2006) Freezing of Epididymal Spermatozoa from Dogs after Cool Storage for 2 or 4 Days. Theriogenology, 66, 1633-1636. https://doi.org/10.1016/j.theriogenology.2006.01.032

[35] Reckova, Z., Machatkova, M., Machal, L. and Jeseta, M. (2015) Relationship between Acrosome İntegrity Changes and in Vitro Fertilizing Ability of Bovine Spermatozoa. Veterinarni Medicina, 60, 469-475.

[36] Sreenivasa, G., Vineeth, V.S., Kavitham, P. and Malini, S.S. (2012) Evaluation of Acrosome Intactness Status in Male Fertility in Mysore, South India. International Journal of Applied Basic Medical Research, 2, 31-33.

[37] Hoseinzadeh-Sani, S.K., Barati, F. and Mahabady, M.K. (2013) The Effects of ex Vivo Cold-Storage on Cryopreservation of the Goat (Caprushircus) Epididymal Sperm. Iranian Journal of Reproductive Medicine, 11, 747-752. 